\title{
Application of Near Infrared Reflectance Spectroscopy to Predict Fecal Composition and Its Use for Digestibility Estimation
}

\author{
Agung PURNOMOADI, Mitsunori KURIHARA*, \\ Takehiro NISHIDA*, Masaki SHIBATA*!, \\ Akira $\mathrm{ABE}^{*}$ and Ken-ichi KAMEOKA \\ Faculty of Agriculture, Tokyo University of Agriculture, \\ Setagaya-ku, Tokyo 155 \\ * National Institute of Animal Industry, Tsukuba Norin Kenkyu Danchi, \\ Ibaraki-ken 305
}

(Received December 27, 1996)

\begin{abstract}
Two experiments were carried out to investigate the applicability of near infrarcd reflectance spectroscopy (NIRS) to predict the chemical composition of feces, and thereby to estimate digestibility based on a lignin indicator method. Ninety five fecal samples collected from digestion trials using dairy cattle were subjected to NIRS for the prediction of chemical composition. Three methods to determine feed digestibility were compared, namely by digestion trial (in vivo), by the lignin indicator method using data from chemical analysis (LIGLab), and by the lignin indicator method from NIRS prediction (LIGNIR). Digestibility was evaluated for three groups of feeds based on the type of feedstuff used in the ration. The groups were Italian ryegrass only ( $I R O, n=20$ ), Italian ryegrass-concentrate ration ( $\mathrm{RCT}, \mathrm{n}=16$ ), and Italian ryegrass -steamed wood ration ( $I R S W, \mathrm{n}=12$ ). The rations were adjusted so as to meet the fotal digestible nutrients requirement of the Japanese Feeding Standard. This study showed that fecal compo* sition could be accurately predicted by NIRS. The values obtained by the NIRS prediction method for unknown samples and the respective values obtained by chemical analysis were highly correlated for acid detergent fiber, crude fiber, lignin and ether extract; the correlation coefficients $(r)$ were $0.98,0.98,0.97$ and 0.96 , respectively. Correlation coefficients for crude protein, organic matter and energy were $0.91,0.91$ and 0.82 , respectively. With respect to digestibility estimation, the value for the LIGLab and LIGNIR estimations and that for the in vivo were very similar. The difference between the LIGLab and LIGNIR values and the in vivo value was below $3 \%$, the standard deviation of difference was less than $5 \%$. The results show that digestibility estimation using lignin determined by NIRS as an indicator was useful for the routine evaluation of nutritive values because it is simple, fast and accurate.
\end{abstract}

Anim. Sci. Technol. (Jpn.) 67 (10) : 851 861,1996

Key words : NIRS, Fecal composition, Lignin, Digestibility, Dairy cattle

A number of studies to determine the nutritive values of feed using near infrared reflectance spectroscopy (NIRS) have been carried out. The success in predicting the chemical composition of various feedstuffs by NIRS ${ }^{3,23)}$ advanced the application of this method to the

1) Present address: Agriculture, Forestry and Fisheries Research Council. Ministry of Agriculture Forestry and Fisheries, Chiyoda-ku, Tokyo 100

Anim. Sci. Technol. (Jpn.) $67(10): 851-861$ 
prediction of nutritive values such as total digestible nutrients (TDN) and available energy contents ${ }^{9,12)}$. All these studies were carried out directly with feeds in which the in vivo digestibility was previously known. However, digestibility is affected by the condition of the animal used, variation between animals as well as feeding level ${ }^{16}$. Therefore, it is possible for the same ration fed to different animals to have different digestibilities, and ideally, digestibility should be individually estimated.

The ideal way to measure digestibility is by the digestion trial method in which feed intake and the nutrients ingested can be accurately measured. However, this method is expensive and laborious. An alternative method in digestibility measurements is the indicator method in which lignin is used as an indicator. This method does not require the total collection of feces, but only needs a representative fecal sample. Only by measuring the percentage of lignin in feed and feces, can the digestibility of the feed be estimated.

Given that the chemical composition of feeds are easily and routinely predicted using NIRS, it may be worth trying to use the same approach to estimate the chemical composition of feces. One extra advantage of this approach is that it takes into account the fraction of ingested nutrients and energy lost in the feces, which accounts for the largest part of feed losses. In ruminants these losses reach 40$50 \%$ and $20-30 \%$ in case of roughage and concentrate, respectively ${ }^{7)}$. Combined with the efficient indicator method, NIRS may be used to generate a faster and more accurate estimation of feed digestibility from individual animals.

The aims of this study were to validate the use of NIRS for the prediction of the chemical composition of feces, and to evaluate the accuracy of digestibility estimation using lignin predicted by NIRS.

\section{Materials and Methods}

\section{Experiment 1.}

Ninety-five fecal samples from a digestion trial using dairy cattle were used in this study. All cattle were fed at the total digestible nutrients (TDN) requirement level of the Japanese Feeding Standard for Dairy Cattle ${ }^{20)}$. The samples were dried at $60^{\circ} \mathrm{C}$ for 48 hours before they were ground with a Wiley mill to pass through a $1.00-\mathrm{mm}$ screen. These processed samples were used for chemical analysis to determine organic matter (OM), crude protein $(\mathrm{CP})$, ether extract $(\mathrm{EE})$, crude fiber $(\mathrm{CF})^{18)}$, acid detergent fiber (ADF), acid detergent lignin (lignin), and silica ${ }^{1}$, as well as energy ${ }^{18}$.

Analysis by NIRS was done by a Pacific Scientific (Neotec) model 6500 (Perstorp Analytical, Silver Spring, MD) instrument equipped with ISI software (InfraSoft International, Port Matilda, PA) for analysis. The samples were scanned over the range $1,100-2,500 \mathrm{~nm}$. The spectral data were collected at wavelength intervals of $2 \mathrm{~nm}$, and the 700 data points obtained for each sample were stored in the computer as absorbance values. These values were expressed as $\log 10(1 / R)$, where $R$ is the reflectance. The second derivative of $\log 1 / R$ values were used to derive relationships with the chemical compositions ${ }^{23)}$. To achieve the optimum wavelengths for predicting the components, a stepwise multiple-linear-regression program was used.

Forty-nine samples chosen randomly from the 95 fecal samples above were used as a standard sample to develop a NIRS calibration equation. This equation was then used to predict the chemical contents of the remaining 46 fecal samples (unknown samples). The calibration was done with a maximum of four wavelengths. The least number of wavelengths was used for mcasurement when an increase in the number of wavelengths gave no increase in significance of the $R$ value nor any decrease in the standard error of calibration. 


\section{Digestibility estimation by NIRS predicted data}

\section{Experiment 2.}

It is well known that prediction by NIRS will be maximal if the calibration set samples and unknown samples are the same or of high homogeneity ${ }^{27)}$. This is because, the feedstuffs were separated into two big groups to develop the calibration equation.

Twenty-five samples of forage including hay, silage, and steamed wood, and 10 samples of concentrate including grains and soybean were used to develop an NIRS calibration equation for forage and concentrate respectively. Due to the limited number of feed samples used, the validity of the developed equations was not tested. Both equations were directly used to determine $\mathrm{OM}, \mathrm{CP}, \mathrm{EE}, \mathrm{CF}, \mathrm{ADF}$, lignin, and energy contents for 10 feedstuffs ( 7 Italian ryegrass, 2 concentrate and 1 steamed wood samples). These feedstuffs were the main components used to make the 48 rations with known in vivo digestibilities. Subsequently the values observed from the 10 feedstuffs were used to calculate the chemical composition of the 48 rations. Based on types of feedstuffs used in the rations, three groups were designed for evaluation. Group I was Italian ryegrass only (IRO) composed of three kinds of Italian ryegrass fed to dairy cattle $(\mathrm{n}=$ 20). Group II was a mixture of Italian ryegrass and concentrate (IRCT) composed of (1) a combination of Italian ryegrass and soybean, (2) a combination of Italian ryegrass and commercial formula feed, and (3) a combination of Italian ryegrass and soybean and commercial formula feed. These rations were fed to dairy cattle $(n=16)$. Group III was a mixture of Italian ryegrass and steamed wood (IRSW) at 5 and $55 \%$ fed to 12 dairy cattle. The separation of rations for evaluation was made to reduce the influence of feedstuff type on digestibility estimation, because of different lignin recoveries ${ }^{15}$. These rations were allowed at the TDN requirement level of the Japanese Feeding Standard for Dairy Cattle ${ }^{20)}$. Finally, the digestibility of each ration was calculated by the lignin indicator method using the formula ${ }^{\text {i) }}$ :

$$
\begin{aligned}
\text { digestibility }= & 100-\{100 \times(\% \text { lignin in } \\
& \text { feeds } / \% \text { lignin in feces }) \\
& \times(\% \text { nutrient in feces } / \\
& \% \text { nutrient in feeds })\}
\end{aligned}
$$

Two approaches were applied to estimate digestibility by the lignin indicator method and both were compared with in vivo digestibility values for their accuracy. The first approach was to calculate the chemical composition of feed and fecal samples obtained from chemical analysis (LIGLab). The second one was to calculate those samples from NIRS data (LIGNIR).

Digestibility values estimated using LIGLab, LIGNIR and in vivo, were compared for $\mathrm{OM}, \mathrm{CP}$, $\mathrm{EE}, \mathrm{CF}, \mathrm{ADF}$ and energy. The differences between individual digestibility values estimated by LIGLab or LIGNIR and in vivo were calculated. These differences were tested for significance using paired $t$-tests ${ }^{28)}$.

\section{Results and Discussion}

\section{Experiment 1.}

The ranges and means of all constituents for the standard and unknown samples are shown in Table 1. Regarding the range of composition, values of the standard samples were slightly wider than those of the unknown samples.

Wavelengths observed for calibration of standard samples are listed in Table 2. With respect to organic matter, the 1 st to 4 th absorbance wavelengths were found at 2,418, 2,206, 1,144 and $1,956 \mathrm{~nm}$, respectively. The first $\mathrm{ab}$ sorbance was in the $2,410-2,460 \mathrm{~nm}$ region, considered to be the second overtone of $\mathrm{C}-\mathrm{H}$ deformation ${ }^{19)}$ and this was related to cellulose. Another report ${ }^{8)}$ found that the first two wavelengths were absorbance values for the detergent fiber component. The 3rd wavelength was close to $1,143 \mathrm{~nm}$, characteristic of aromatic structures ${ }^{25)}$ which is thought to be lignin ${ }^{22)}$. The 4 th wavelength which was close to 1,960 


\section{PURNOMOADI, KURIHARA, NISHIDA, SHIBATA, ABE and KAMEOKA}

Table 1. Means and ranges of constituents for calibration of standard samples and prediction of unknown fecal samples

\begin{tabular}{lccccc}
\hline \multirow{2}{*}{ Constituents } & \multicolumn{2}{c}{ Standard $(\mathrm{n}=49)$} & & \multicolumn{2}{c}{ Unknown $(\mathrm{n}=46)$} \\
\cline { 2 - 3 } \cline { 5 - 6 } & Mean & Range & & Mean & Range \\
\hline Organic matter & 85.1 & $66.2-94.1$ & & 85.7 & $70.8-94.5$ \\
Crude protein & 12.6 & $4.9-25.3$ & & 12.0 & $5.7-23.8$ \\
Ether extracts & 1.9 & $0.5-3.0$ & & 1.8 & $0.4-3.5$ \\
Crude fiber & 29.9 & $19.2-45.9$ & & 31.3 & $18.7-41.2$ \\
Acid detergent fiber & 47.5 & $27.4-68.1$ & & 48.5 & $34.4-64.2$ \\
Energy & 4.412 & $3,276-4.897$ & & 4,439 & $3,756-5,065$ \\
Lignin & 14.7 & $9.6-25.3$ & & 14.6 & $9.5-27.6$ \\
Silica & 6.3 & $0.9-27.4$ & & 5.9 & $0.8-16.4$ \\
\hline
\end{tabular}

$\mathrm{n}=$ number of samples

Table 2. Wavelengths used and correlation coefficients of each constituent for fecal calibration of standard and prediction of unknown fecal samples*)

\begin{tabular}{|c|c|c|c|c|c|c|c|c|}
\hline \multirow{2}{*}{ Constituents } & \multicolumn{4}{|c|}{ Wavelength (nm) } & \multicolumn{2}{|c|}{ Standard $(n=49)$} & \multicolumn{2}{|c|}{ Unknown $(n=46)$} \\
\hline & 1st & 2nd & $3 r d$ & 4 th & $\mathrm{R}$ & $\mathrm{SeC}$ & $\mathrm{r}$ & $\mathrm{SeP}$ \\
\hline Organic matter & 2,418 & 2,206 & 1,144 & 1,956 & 0.957 & 1. 29 & 0.911 & 0.35 \\
\hline Crude protein & 2,186 & 2,090 & 2,396 & - & 0.988 & 0.70 & 0.912 & 0.09 \\
\hline Ether extracts & 1,470 & 2.334 & 1,690 & - & 0.983 & 0.14 & 0.956 & 0.02 \\
\hline Crude fiber & 2,332 & 1,820 & 2,452 & 1,954 & 0.983 & 1.22 & 0.976 & 0.19 \\
\hline Acid detergent fiber & 2,300 & 1,330 & - & - & 0.987 & 1.45 & 0.979 & 0.12 \\
\hline Energy & 2,420 & 1,572 & 2,036 & 1,602 & 0.931 & 70.6 & 0.819 & 21.1 \\
\hline Lignin & 2,388 & 1,760 & 2,318 & - & 0.971 & 1.07 & 0.972 & 0.15 \\
\hline Silica & 2,220 & 1,372 & 1,694 & - & 0.925 & 0.86 & 0.792 & 0.06 \\
\hline
\end{tabular}

${ }^{*} \mathrm{R}$ : correlation coefficient from multiple regression ; $\mathrm{r}$ : correlation coefficient from simple regression ; SeC : standard error of calibration; SeP : standard error of prediction.

nm, was for protein ${ }^{25)}$.

Three wavelengths at 2,186, 2,090 and 2,396 $\mathrm{nm}$ were recorded for the calibration of $\mathrm{CP}$. The 1st wavelength was protein at $2,180 \mathrm{~nm}^{25)}$. The 2nd wavelength was considered to be cellulose at $2,088 \mathrm{~nm}^{25}$ ), while the $3 \mathrm{rd}$ wavelength at $2,396 \mathrm{~nm}$ was close to the $2,380 \mathrm{~nm}$ of hemicellulose $\mathrm{e}^{25)}$.

Three wavelengths at 1,470,2,334 and 1,690 $\mathrm{nm}$ were recorded for the calibration of $\mathrm{EE}$. The 1st wavelength was $19 \mathrm{~nm}$ different from the $1,489 \mathrm{~nm}$ of cellulose $\mathrm{e}^{25}$. The $2 \mathrm{nd}$ and $3 \mathrm{rd}$ wavelengths were very close to 2,336 and 1,685 $\mathrm{nm}$ which are known to be the absorbance of cellulose and lignin ${ }^{22,25)}$, respectively. These wavelengths demonstrated that dominant fecal fibrous components were used in determining ether extract. Ether extracts in feces is the smallest constituent and does not clearly appear in $\log 1 / R$. Consequently, the wavelength properties of $\mathrm{EE}$ might be concealed by the more dominant spectrum of cellulose.

Crude fiber (CF) was well predicted by using four wavelengths at 2,332, 1,820,2,452 and 1,954 $\mathrm{nm}$. The first two wavelengths were close to the absorbance of cellulose, at 2,336 and 1,820 $\mathrm{nm}^{25}$. The $3 \mathrm{rd}$ and 4 th wavelengths were close to the $2,461 \mathrm{~nm}$ absorbance of starch and $1,960 \mathrm{~nm}$ absorbance of protein ${ }^{25)}$. The first 
Digestibility estimation by NIRS predicted data

two wavelengths are known to be the most important as cellulose is the most important component of CF. The 3rd wavelength, that of starch, was considered to be important, as starch is structurally similar to cellulose. The 4th wavelength, that of protein, apparently has no relation with $C F$, and was simply used to improve the correlation coefficient in this regression.

Only two wavelengths at 2,300 and $1,330 \mathrm{~nm}$ were used for the calibration of ADF. The first wavelength was close to the $2,294 \mathrm{~nm}$ of neutral detergent fiber $(\mathrm{NDF})^{23)}$. The second wavelength was related to that of hemicellulose at $1,360 \mathrm{~nm}^{25)}$. Hemicellulose with cellulose and lignin form NDF, but hemicellulose does not form a part of ADF which contains just cellulose and lignin. The appearance of NDF or hemicellulose absorbance in ADF was related to the fact that both cellulose and hemicellulose are carbohydrates in which they have the same absorbance region.

For lignin, three wavelengths were observed, which were $2,388,1,760$ and $2,318 \mathrm{~nm}$. The $1 \mathrm{st}$ and 2nd wavelengths were close to the reported absorbances of in vitro dry matter digestibility (IVDMD) at $2,386 \mathrm{~nm}^{13)}$ and at 1,759 $\mathrm{nm}^{29)}$, respectively. The $3 \mathrm{rd}$ wavelength was considered to be hemicellulose, which is usual1y observed at $2,314 \mathrm{~nm}^{25}$.

The four wavelengths observed for energy were $2,420,1,572,2,036$ and $1,602 \mathrm{~nm}$. The first wavelength was the same as the first wavelength of organic matter, which was considered to be cellulose. The 2 nd wavelength was close to either the reported $1,570 \mathrm{~nm}$ of cell wall $^{6)}$ or the $1,580 \mathrm{~nm}$ of ccllulosc ${ }^{25)}$. The $3 \mathrm{rd}$ wavelength at $2,036 \mathrm{~nm}$ was $14 \mathrm{~nm}$ different from $2,050 \mathrm{~nm}$, which is the absorbance of protein $^{13)}$. The fourth wavelength at $1,602 \mathrm{~nm}$ was considered to be the absorbance of organic matter. That was close to the $1,606 \mathrm{~nm}$ absorbance of organic matter ${ }^{3)}$, and the $1,610 \mathrm{~nm}$ absorbance for IVDMD, the first wavelength from five wavelengths reported by Holechek et $a l^{13)}$.
The four wavelengths observed here were in agreement with the fact that organic matter is closely related to energ $y^{5)}$.

For silica, three wavelengths were observed at 2,220, 1,372 and $1,694 \mathrm{~nm}$. The first wavelength was close to the reported 2,212 and 2,214 $\mathrm{nm}$ of the digestible fraction of cell wall ${ }^{3 !}$. The 2 nd and the 3 rd wavelengths were close to the $1,365 \mathrm{~nm}$ of cellulose $\mathrm{e}^{25)}$ and $1,685 \mathrm{~nm}$ of lignin ${ }^{22,25)}$, respectivcly.

Correlation coefficients ( $R$ ) between the values obtained by chemical analysis method and those obtained by NIRS for all constituents in the standard samples were observed to be more than 0.90 . The highest $\mathrm{R}, 0.988$, was found for CP while the lowest, 0.925 , was for silica. As presented in Table 2, $R$ values for the fibrous fractions were very close to one, being $0.983,0.987$, and 0.971 for CF, ADF, and lignin, respectively. High $\mathrm{R}$ values were also found for $\mathrm{OM}, \mathrm{EE}$ and energy contents, being $0.957,0.983$ and 0.931 , respectively. For validity of equations developed, the prediction equations in the standard samples were tested for further application.

The prediction equation obtained from the standard samples was used to determine the constituents of 46 unknown samples. Except for CF and lignin, the simple correlation coefficient (r) and standard errors (SeP) were generally lower than those for the standard samples. Because of the higher similarity of $\mathrm{R}$ values for lignin in the standard and unknown samples, it may lead to a possibility of lignin as an indicator for digestibility estimation.

The decrease in the correlation coefficient values of ADF, EE, OM and CP observed from the calibration of standard samples compared to that from the prediction of the unknown samples was small. A remarkable decrease of the correlation coefficient was observed for silica (from 0.925 to 0.792 ) and energy (from 0.931 to 0.819 ). This result shows that silica was poorly predicted. It agrees with the finding that minerals are known to have no 


\section{PURNOMOADI, KURIHARA, NISHIDA, SHIBATA, ABE and KAMEOKA}

absorption bands in the near infrared region ${ }^{27)}$. In case of energy, using only four wavelengths, which is the maximum capacity of instrument used, may not satisfy the requirements for fecal prediction because of spectral complications resulting from the wide possibility of combinations. This was due to the fact that energy is the heat contributed from all chemical components in the samples.

Reviewing the absorbances observed, the wavelengths appropriate for feces were somewhat different from that usually observed for feed. The wavelengths observed for all constituents in feces were dominantly in the cellulose spectra for predicting chemical composition. Reference to wavelengths obtained only from feed made it difficult to conclude whether the wavelengths obtained were appropriate for feces. However, the obtained wavelengths were still related to the chemical composition predicted.

\section{Experiment 2.}

The ranges and means of feedstuffs for NIRS calibration in this study are presented in Table
3. In forage, high $\mathrm{R}$ values were found for $\mathrm{OM}$, $\mathrm{CP}, \mathrm{CF}, \mathrm{ADF}$, and lignin, ranging from 0.978 to 0.986. Lower $\mathrm{R}$ values were found for $\mathrm{EE}$ and energy, being 0.834 and 0.770 , respectively. In addition, in concentrate, high $R$ values were also found for $\mathrm{OM}, \mathrm{CP}, \mathrm{EE}, \mathrm{ADF}$, energy, and lignin, ranging from 0.992 to 0.997 . A lower $\mathrm{R}$ value, 0.907 , was found only for crude fiber. The high calibration $R$ values for lignin in both forage and concentrate suggests that lignin in feed may be well predicted and can be used for digestibility estimation based on lignin.

The chemical compositions of 48 rations, classified into three groups, IRO, IRCT, IRSW are presented in Table 4. The chemical composition of the feedstuff groups were calculated using the data obtained from chemical analysis and from NIRS prediction of the 7 roughages, 2 concentrates and 1 steamed wood components. Referring to mean values, only small differences between the two methods of calculation were observed for all constituents. Relatively large differences were observed only in ADF of IRO and CF of IRSW, being 1.7 and

Table 3. Means, ranges and wavelengths used for NIRS calibration of feedstuff samples*)

\begin{tabular}{|c|c|c|c|c|c|c|c|c|}
\hline \multirow{2}{*}{ Constituents } & \multirow{2}{*}{ Mean } & \multirow{2}{*}{ Range } & \multicolumn{4}{|c|}{ Wavelength (nm) } & \multirow{2}{*}{$\mathrm{R}$} & \multirow{2}{*}{$\mathrm{SeC}$} \\
\hline & & & 1st & 2nd & 3rd & 4 th & & \\
\hline \multicolumn{9}{|l|}{ Roughage $(n=25)$} \\
\hline Organic matter & 90.3 & $87.9-99.6$ & 1,486 & 2,266 & - & - & 0.978 & 0.61 \\
\hline Crude protein & 9.2 & $0.1-12.4$ & 2,188 & 1,228 & - & 一 & 0.986 & 0.54 \\
\hline Ether extracts & 2.6 & $0.8-3.4$ & 1,684 & 1,286 & 1,220 & 2,040 & 0.834 & 0.46 \\
\hline Crude fiber & 31.1 & $24.7-47.8$ & 2,184 & 1,606 & 2,360 & - & 0.984 & 1.01 \\
\hline Acid detergent fiber & 39.4 & $30.8-68.1$ & 1,740 & 2,378 & - & - & 0.981 & 1.75 \\
\hline Energy & 4,305 & $4,177-4,770$ & 1.822 & 1,692 & 2,322 & 1,964 & 0.770 & 83.7 \\
\hline Lignin & 6.2 & $3.0-16.5$ & 2,378 & 1,670 & 一 & - & 0.981 & 0.64 \\
\hline \multicolumn{9}{|l|}{ Concentrate $(n=10)$} \\
\hline Organic matter & 93.2 & 92.894 .3 & 1,142 & 2,258 & 1,490 & 2,032 & 0.922 & 0.07 \\
\hline Crude protein & 19.1 & $14.4-50.7$ & 2,132 & - & - & - & 0.993 & 1.41 \\
\hline Ether extracts & 3.0 & $1.7-3.5$ & 1,974 & 2,256 & 1,394 & 2,446 & 0.986 & 0.09 \\
\hline Crude fiber & 5.6 & $4.2-7.6$ & 1,328 & 1,808 & 1,140 & - & 0.907 & 0.43 \\
\hline Acid detergent fiber & 9.7 & $7.8-13.6$ & 1,212 & 2,152 & 1,992 & - & 0.995 & 0.22 \\
\hline Energy & 4,398 & $4,308-4,864$ & 2,132 & 1,682 & - & - & 0.997 & 12.1 \\
\hline Lignin & 1.8 & $0.3-3.5$ & 1,722 & 1,520 & 1,190 & 1,810 & 0.992 & 0.12 \\
\hline
\end{tabular}

*) $\mathrm{R}$ : correlation coefficient from multiple regression; SeC : standard error of calibration. 
Digestibility estimation by NIRS predicted data

Table 4. Means of chemical composition of the ration groups used in this study as calculated with chemical analysis data and NIRS predicted data $(\% \mathrm{DM})^{*)}$

\begin{tabular}{|c|c|c|c|c|c|c|}
\hline \multirow{2}{*}{ Constituents } & \multicolumn{2}{|c|}{$\operatorname{IRO}(n=20)$} & \multicolumn{2}{|c|}{$\operatorname{IRCT}(\mathrm{n}=16)$} & \multicolumn{2}{|c|}{ IRSW $(n=12)$} \\
\hline & Lab & NIR & Lab & NIR & Lab & NIR \\
\hline Organic matter & 90.0 & 89.9 & 92.1 & 92.4 & 93.0 & 92.7 \\
\hline Crude protein & 9.0 & 9. 1 & 23.8 & 24.6 & 8.3 & 7.9 \\
\hline Ether extracts & 2.5 & 2.7 & 3.1 & 2.8 & 2.4 & 2.5 \\
\hline Crude fiber & 30.3 & $30 . ?$ & 13.7 & 13.5 & 31.8 & 33.0 \\
\hline Acid detergent fiber & 36.4 & 38.1 & 19. 1 & 18.9 & 43. 9 & 43. 2 \\
\hline Energy $^{1)}$ & 4,266 & 4,289 & 4,487 & 4,482 & 4,470 & 4,415 \\
\hline Lignin & 5.2 & 5.7 & 2.7 & 2.6 & 7.1 & 7.5 \\
\hline
\end{tabular}

*) Feed composition calculation of 48 rations used the data of 7 roughage, 2 concentrate and 1 steamed wood feed obtained from chemical analysis (Lab) and NIRS prediction (NIR); IRO : Italian ryegrass only, IRCT : Italian ryegrass-concentrates, IRSW : Italian ryegrass-steamed wood.

${ }^{1}$ Energy expressed in cal/g DM.

$1.2 \%$, respectively. Other constituents were below $0.6 \%$. For energy, a large difference was only observed for IRSW, being $55 \mathrm{cal} / \mathrm{g}$.

The mean digestibility calculated from the three methods as well as the standard deviation of difference (SDd) between both LIGLab or LIGNIR, and that in vivo are shown in Table 5. The evaluation was done for 3 groups separated on the basis of type of feedstuffs.

In general, the estimated values were slightly higher than the in vivo values. A comparison between LIGLab and LIGNIR, for the IRO and IRSW groups indicates that the LIGLab estimated value was higher than that of LIGNIR. However, the contrary was observed for the IRCT group. These figures may be caused by the NIRS predicted data for lignin of the rations (Table 4). Due to the equation for digestibility estimation used, the estimation value will be lower if the value of lignin of feces is low or lignin of feeds is high.

For a comparison of the means between the digestibility estimated by LIGNIR and in vivo, the difference observed in DM and $O M$ were 2.3, $1.4,2.0$ and $3.0,1.1,1.7 \%$ for the IRO, IRCT, IRSW groups, respectively. These differences are relatively small. For $\mathrm{CP}$ and $\mathrm{EE}$ digestibility, the differences of means were $1.2,1.6,5.8$ and $0.9,0.5,4.8 \%$ for the IRO, IRCT and IRSW groups, respectively. The different values observed for the IRO and IRCT groups were small, but were relatively high for the IRSW group. Small differences were observed in CF and ADF digestibility, being 0.5, 0.6, 2.8 and 2.1, $0.3,1.2 \%$ for the IRO, IRCT and IRSW groups, respectively. For the digestibility of energy, the differences of means for IRO, IRCT and IRSW groups were $2.4,1.5$ and $1.6 \%$, respectively. From these differences, the digestibility estimated with LIGNIR were very similar to the values obtained in vivo, except for the digestibility of $\mathrm{CP}$ and $\mathrm{EE}$ for the IRSW group. For comparison, Penning and Johnson ${ }^{26)}$ using acid insoluble ash (AIA) as a marker observed the mean differences of OM digestibility at 0.9 and $1.8 \%$ for sheep fed ryegrass at 15 and $25 \mathrm{~g}$ per $\mathrm{kg}$ live weight, respectively.

Referring to the standard deviation of difference (SDd) between the estimation values of LIGLab or LIGNIR and that in vivo, the values were generally below $5 \%$ for the IRO and IRCT groups, except for the digestibility of CP of the IRO group. For the IRSW group, the SDd was relatively high. The accuracy of digestibility estimations of similar studies to the present experiment were expressed by the residual standard deviation (RSD) which was observed as the differences between the in vivo value and 
PURNOMOADI, KURIHARA, NISHIDA, SHIBATA, ABE and KAMEOKA

Table 5. Digestibility value estimated from LIGLab and LIGNIR in comparison with the in vivo method

\begin{tabular}{|c|c|c|c|c|c|c|}
\hline \multirow{2}{*}{$\begin{array}{c}\text { Digestibility of } \\
\text { constituents }\end{array}$} & \multicolumn{2}{|c|}{ LIGLab } & \multicolumn{2}{|c|}{ LIGNIR } & \multicolumn{2}{|c|}{ In vivo } \\
\hline & Mean & SDd & Mean & SDd & Mean & Range \\
\hline & \multicolumn{6}{|c|}{ - Italian ryegrass only (IRO, $\mathrm{n}=20)$} \\
\hline Dry matter & 53.3 & 4.849 & $49.6^{*}$ & 4. 261 & 51.9 & $39.1-68.4$ \\
\hline Organic matter & 55.6 & 4.508 & 51. $4^{* *}$ & 4. 346 & 54.4 & $41.3-71.7$ \\
\hline Crude protein & 46.1 & 6.180 & 43. 1 & 6.118 & 44.3 & $32.8-58.0$ \\
\hline Ether extracts & 66.5 & 3. 455 & 66.2 & 3. 243 & 65.3 & $54.2-74.9$ \\
\hline Crude fiber & $50.4^{*}$ & 4.514 & 48.5 & 4.505 & 48.0 & $31.2-68.3$ \\
\hline Acid detergent fiber & 38.3 & 4. 790 & 36.9 & 4.827 & 39.0 & $22.7-59.9$ \\
\hline \multirow[t]{2}{*}{ Energy } & 52.6 & 4.877 & 48. $8^{*}$ & 4. 217 & 51.2 & 38. $1-68.8$ \\
\hline & \multicolumn{6}{|c|}{ - Italian ryegrass - concentrates (IRCT, $\mathrm{n}=16$ ) } \\
\hline Dry matter & 72.6 & 2.312 & $73.5^{*}$ & 2.266 & 72.1 & $65.3-77.6$ \\
\hline Organic matter & 75.1 & 2. 100 & $75.8^{*}$ & 2.110 & 74.7 & $68.9-79.0$ \\
\hline Crude protein & 72.5 & 2.596 & 33.7 & 3. 402 & 72.1 & $57.2-83.1$ \\
\hline Ether extracts & 76.9 & 4. 139 & 78.2 & 2.666 & 77.7 & $63.2-82.1$ \\
\hline Crude fiber & 52.1 & 2. 454 & 52.5 & 3.457 & 51.9 & $44.6-57.8$ \\
\hline Acid detergent fiber & 47.0 & 4.851 & 47.5 & 3.656 & 47.8 & $35.7-56.2$ \\
\hline \multirow[t]{2}{*}{ Energy } & 72.7 & 2.222 & $73.6^{*}$ & 2.116 & 72.1 & $65.8-77.2$ \\
\hline & & \multicolumn{4}{|c|}{ Italian ryegrass-steamed wood (IRSW, $\mathrm{n}=12$ ) } & \\
\hline Dry matter & $62.0^{*}$ & 5.977 & 58.9 & 4. 300 & 56.9 & $44.5-67.4$ \\
\hline Organic matter & $63.4^{*}$ & 5.518 & 60.3 & 4. 375 & 58.6 & 45. $1-70.2$ \\
\hline Crude protein & 45. $3^{* *}$ & 8.165 & 43. $7^{* *}$ & 5.673 & 37.9 & $15.9-55.0$ \\
\hline Ether extracts & $71.0^{*}$ & 6.333 & 71. $1^{* *}$ & 3. 340 & 66.3 & $62.2-71.8$ \\
\hline Crude fiber & $62.7^{* *}$ & 4. 751 & $60.8^{* *}$ & 3. 246 & 57.9 & $34.0-71.8$ \\
\hline Acid detergent fiber & 53. $9^{* *}$ & 4. 551 & 50.0 & 2.652 & 48.8 & $29.9-62.4$ \\
\hline Energy & 60.5 & 5.875 & 56.5 & 5.748 & 54.9 & $40.1-66.8$ \\
\hline
\end{tabular}

*) Significant $(P<0.05)$, **) significant $(P<0.01)$; SDd : standard deviation of difference between estimation values of the LIGLab or LIGNIR and the in vivo, Dry matter digestibility $=100-(100 \times$ lignin feed $/$ lignin feces).

the estimation adjusted value resulting from the regression equation. These $\mathrm{RSD}$ values represented the estimation variation associated with the techniques. Standard deviation of differences and RSD are comparable because they are both calculated by the difference between values determined in vivo and those estimated. The RSD of dry matter (DM) digestibility estimated using lignin determined by three methods ranged from 2.4 to $4.5^{17}$, while the same estimation made using cellulase digestion methods was in the range of 2.5 to $2.7^{14)}$.

For OM digestibility, Navaratne et al. ${ }^{21}$ reported the prediction of roughages (grass and straw) by various methods. These methods used AIA as a marker $(\mathrm{RSD}=4.06$ ), rumen fluid $(\mathrm{RSD}=3.78$ ), pepsin-cellulase ( $\mathrm{RSD}$ $=5.09$ ) and nylon bag methods ( $\mathrm{RSD}=4.08$ ). If the comparison is done based on type of feed, RSD values observed for the grass group using AlA marker, rumen fluid, pepsin-cellulase and nylon bag methods, however, were lower by $1.78,1.66,1.40$, and 1.24 than the results of the present experiment, respectively. The estimation of OM digestibility in this study was also similar to that reported by Aerts et $a l^{2)}$ who used two-stage in vitro digestibility method. 
A relatively high SDd was observed for digestibility of CP in the IRO and IRSW groups, and for digestibility of energy in the IRSW group. These estimations are less accurate than other components, although this is statistically not significant. The high SDd of $\mathrm{CP}$ digestibility observed in the IRO and IRSW groups were merely caused by the wide range of $\mathrm{CP}$ digestibility for the low $\mathrm{CP}$ content in the feed (both groups were below 10\% CP). However, evaluation of $\mathrm{CP}$ can be neglected for ruminants due to the involvement of non protein nitrogen (NPN) in the calculation ${ }^{24)}$. Meanwhile, the high SDd for digestibility of energy in the IRSW group was considered to be influenced by the poor energy prediction of the feedstuff in that group (see Table 4). A comparison of observed SDd with the RSD reported from the various methods above indicates that the estimation method used in this study was apparently favorable.

The most favorable estimation of digestibility in the IRCT group, as indicated by the smallest bias and SDd among the rations, was related to the accuracy of lignin prediction of feedstuffs. Since usual farming management would use a combination of roughage and concentrate, this digestibility estimation shows the applicability for farms. To improve the accuracy of this method, a larger sample number and wider range of feedstuffs for developing NIRS prediction equations should be considered.

In practice, only $\mathrm{DM}$ digestibility ${ }^{30)}$ or $\mathrm{OM}$ digestibility $^{2)}$ would be used for evaluating feeding management. The differences between the lignin indicator methods and the in vivo method were related to the fact that lignin was partially digestible $\mathrm{e}^{10,11,15)}$. Van Soest ${ }^{30)}$ noted that the limitation of using lignin as a digestibility indicator is limited because of the large inter-species variation. However, this can be overcome by using fairly similar feedstuffs, although under these conditions standard error is still about $3 \%$ of digestibility.
Thus, the results above show that this digestibility estimation method is sufficiently reliable.

Digestibility estimation by LIGNIR shows the potential for individual and routine meas. urement. Near infrared reflectance spectroscopy prediction of the chemical composition of feces and feed as well as the application of NIRS prediction for digestibility estimation may be useful for the evaluation of feedstuffs on a practical farm basis, provided some correction factors or equations are devised to minimize the difference between in vivo and that estimated by LIGNIR.

\section{Acknowledgements}

The authors wish to thank Dr. F. Terada for reading the manuscript and for his valuable comments, Dr. M. Amari for assisting in the NIRS analysis, and Ms. M. Someya for assisting with the chemical analysis. The authors are also indebted to Dr. Muladno for assisting with the writing.

\section{References}

1) Abe A. Feed analyses based on the carbohydrates and its application to the nutritive value of feeds. Mem. Nat. Inst. Anim. Ind. No 2. 23-29. National Institute of Animal Industry, MAFF. Tsukuba, Japan. 1988. (In Japanese)

2) Aerts JV, De Brabander DL, Cottyn BG, Buysse FX. Comparison of laboratory methods for predicting the organic matter digestibility of forages. Anim. Feed Sci. Technol., $2: 337-349$. 1977.

3) Anari M, Abe A, Tano R, Masaki S, Serizawa $\mathrm{S}$, Koga T. Prediction of chemical composition and nutritive value of forages by near infrared reflectance spectroscopy, 1. Prediction of chemical composition. J. Japan Grassl. Sci., 33 : 219-226 (in Japanese with English summary). 1987.

4) American Society of Animal Science. Tech niques and Procedures in Animal Production Research. American Society of Animal Science. 179. Albany 10. NY. 1963.

5) Armstrong DG. Evaluation of artificially dried grass as a source of energy for sheep. II. The energy value of cocksfoot, timothy and two 


\section{PURNOMOADI, KURIHARA, NISHIDA, SHIBATA, ABE and KAMEOKA}

strains of rye-grass at varying stages of maturity. J. Agric. Sci. Camb., 62 : 399-416. 1964.

6) Barnes RJ. Near infra-red spectra of ammonia -treated straw and isolated cell walls. Anim. Feed Sci. Technol., 21 : 209-218. 1988.

7) Bondy AA. Animal nutrition. 304. A WileyInterscience Publication. John Wiley \& Sons Ltd. Chichester New York Brisbane Toronto Singapore. 1987.

8) Coelho M, Hembry FG, Barton FE, Saxton AM. A comparison of microbial, enzymatic, chemical and near-infrared reflectance spectroscopy methods in forage evaluation. Anim. Feed Sci. Technol., $20: 219-231.1988$.

9) De Boever JL, Cottyn BG, Vanacker JM, Boucque $\mathrm{ChV}$. The use of nirs to predict the chemical composition and the energy value of compound feeds for cattle. Anim. Feed Sci. Technol., 51 : 243-253. 1995.

10) Elam CJ, Davis RE. Lignin excretion by cattle fed a mixed ration. J. Anim. Sci., $20: 484-486$. 1961.

11) Ely RE, Kane EA, Jacobson WC, Moore LA Studies on the composition of lignin isolated from orchard grass hay cut at four stages of maturity and from the corresponding feces. J. Dairy Sci., $36: 346-355.1953$.

12) Givens DI, Baker CW, Adamson AH, Moss AR. Influence of growth type and season on the prediction of the metabolisable energy content of herbage by near-infrared reflectance spectroscopy. Anim. Feed Sci. Technol., $37: 281-$ 295. 1992.

13) Holechek JL, Shenk JS, Vavra M, Arthun D. Prediction of forage quality using near infrared reflectance spectroscopy on esophageal fistula samples from cattle on mountain range. J. Anim. Sci., 55 : 971-975. 1982.

14) Jones DIH, Hayward MV. A cellulase digestion technique for predicting the dry matter digest. ibility of grasses. J.Sci. Food Agric., 24 : 14191426. 1973.

15) Kane EA, Ely RE, Jacobson WC, Moore LA. A Comparison of various digestion trial techniques with dairy cattle. J. Dairy Sci., $36: 325-$ 333. 1953.

16) Leaver JD, Campling $\mathrm{RC}$, Holmes $\mathrm{W}$. The effect of level feeding on the digestibility of diets for sheep and cattle. Anim. Prod., 11 : 11-18. 1969.

17) McLeod MN, Minson DJ. The accuracy of predicting dry matter digestibility of grasses from lignin analysis by three different methods. J. Sci. Food Agric., 25 : 907-911. 1974.
18) Morimoto H. Dobutsu eiyo shikenho (Experimental method of animal nutrition). 280-297, 349. Yokendo. Tokyo. 1971. (in Japanese).

19) Murray I, Williams PC. Chemical principles of near-infrared technology, in : near infrared technology in agricultural and food industries. Williams PC, Norris KH. 30-31. American association of cereal chemists, Inc. St. Paul, Minnesota, USA. 1990.

20) National Research Council of Agriculture, For estry and Fisheries. Japanese Feeding Stand ard for Dairy Cattle. 66-68. NRCAFF, Ministry of Agriculture, Forestry and Fisheries. 1987.

21) Navaratne HVRG, Ibrahim MNM, Schiere JB. Comparison of four techniques for predicting digestibility of tropical feeds. Anim Feed Sci. Technol., $29: 209-221.1990$.

22) Nihon souchi kyoukai. Soushiryou no hinshitsu hyouka gaidobukku-jikyuu shiryou hinshitsu hyouka kenkyuukaihen. 41. Kyouwa. Tokyo. 1995. (In Japanese)

23) Norris KH, Barnes RF, Moore JE, Shenk JS. Predicting forage quality by infrared reflectance spectroscopy. J. Anim. Sci., $43:$ 887-889. 1976.

24) Orskov ER. Protein nutrition in ruminants. 2 nd edition. 89, 157. Academic Press Ltd. London. 1992.

25) Osborne BG, Fearn T. Near infrared spectroscopy in food analysis. 37-40, 133. Longman Scientific \& Technical, Longman Group UK Limited. England. 1986.

26) Penning PD, Johnson RH. The use of internal markers to estimate herbage digestibility and intake, 1. Potentially indigestible cellulose and acid insoluble ash. J. Agric. Sci. Camb., 100 : 127-131. 1983.

27) Shenk JS, Westerhaus MO, Hoover MR. Analysis of forages by infrared reflectance. J. Dairy Sci., 62 : 807. 1979.

28) Snedecor GW, Cochran WG. Statistical Methods. 9th printing, Sixth edition. 91-119. The lowa State University Press. Ames. Iowa, USA. 1978.

29) Valdes EV, Hunter RB, Jones GE. Comparison of near infrared calibration for estimating in vitro digestibility in whole-plant corn hybrids. Can. J. Anim. Sci., 67 : 557-562. 1987.

30) Van Soest PJ. Laboratory methods for evaluating the energy value of feedstuffs, in : Feed energy sources for livestock. Swan $\mathrm{H}$ and Lewis D. 83-94. Butterworth \& Co Ltd. London. 1976. 


\title{
近赤外分析法の共中の成分と消化率推定への適用
}

\author{
Agung PURNOMOADI ・栗原光規* ·西田武弘* \\ 柴田正貴*1・阿部 亮*・亀岡暄一 \\ 東京農業大学農学部, 東京都世田谷区 156 \\ *農林水産省畜産試験場，茨城県筑波農林研究寺地 305
}

乳牛の全霬採取法に上る消化試験試料を用いて，䔬の化学成分含量推定とリグニンを指標とする飼料 消化率推定への近赤外分析法 (以下, NIRS) の適用を検討した，化学成分含量推定には消化試験の粪 95 点を, 飼料消化率推定には 48 組の飼料之冀を用いた。飼料消化率推定においては, 全粪採取法により測 定した消化率 (in vivo 法), 化学分析により測定した試料のリグニンと各種成分含量から求めた消化率 （LIGLab 法）㧍よび近赤外分析法に上り推定した武料のリグニンと各種成分含量から求めた消化率

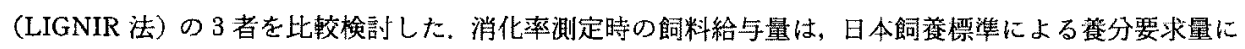
適合させた，その結果，以下のような知見を得た。(1)蕒の化学成分含量は, NIRSにより高い精度で推定 できた. (2) 未知試料 (黛) の NIRSに上る推定值と公定法に上る化学分析值之の相関係数は, 酸性ブ タージェント絨維, 粗織維, リグニンおよび粗脂肪においてそれでれ $0.98,0.98,0.97$ および 0.96 之高い 值を示した． 粗蛋白質，有機物およびエネルギーにおける相関係数は，それぞれ $0.91 ， 0.91$ および 0.82 であった．(3)LIGLab 法あるいはLIGNIR 法による推定消化率は in vivo 法に比較して幾分高い值を示

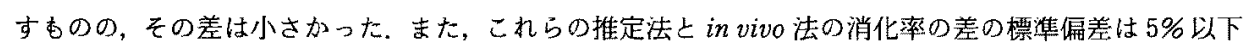

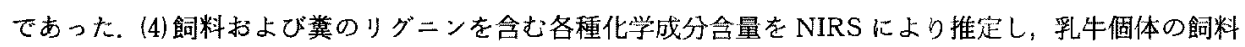
消化率を推定する方法は，迅速，簡便であり，加，酪農現場に扔いて乳牛の飼料利用性を評価するた めには十分な精度をすっている有効な手法と考えられた。

日畜会報, $67(10): 851-861,1996$

1 現所属 : 農林水産省農林水産技術会議，東京都干代田区 100

日音会報，67（10）：851-861 